University of Alaska Southeast

From the ScholarWorks@UA collection of Brian Buma

March 6, 2018

\title{
Populus tremuloides seedling establishment: An underexplored vector for forest type conversion after multiple disturbances
}

Nathan S. Gill, Florencia Sangermano, Brian Buma, Dominik Kulakowski

Originally published in: Gill, Nathan S., Florencia Sangermano, Brian Buma, and Dominik Kulakowski. "Populus tremuloides seedling establishment: An underexplored vector for forest type conversion after multiple disturbances." Forest Ecology and Management 404 (2017): 156-164.

\section{× ScholarWorks@UA}

Available at: $\underline{\text { https://scholarworks.alaska.edu/handle/11122/8170 }}$ 


\title{
Populus tremuloides seedling establishment: An underexplored vector for forest type conversion after multiple disturbances
}

\author{
Nathan S. Gill ${ }^{\mathrm{a}, \mathrm{b}, *}$, Florencia Sangermano ${ }^{\mathrm{a}, \mathrm{c}}$, Brian Buma ${ }^{\mathrm{d}}$, Dominik Kulakowski ${ }^{\mathrm{a}}$ \\ a The Graduate School of Geography, Clark University, 950 Main St., Worcester, MA 01610, USA \\ b Pacific Island Ecosystems Research Center, 344 Crater Rim Drive, Volcano, HI 96718, USA \\ c Clark Labs, Clark University, 950 Main St, Worcester, MA 01610, USA \\ d Department of Natural Sciences, University of Alaska Southeast, 11120 Glacier Highway, Juneau, AK 99801, USA
}

\section{A R T I C L E I N F O}

\section{Keywords:}

Adaptive resilience

Aspen sexual reproduction

Compounded disturbance

Post-fire regeneration

Seral versus stable aspen communities

Species distribution model

\begin{abstract}
A B S T R A C T
Ecosystem resilience to climate change is contingent on post-disturbance plant regeneration. Sparse gymnosperm regeneration has been documented in subalpine forests following recent wildfires and compounded disturbances, both of which are increasing. In the US Intermountain West, this may cause a shift to non-forest in some areas, but other forests may demonstrate adaptive resilience through increased quaking aspen (Populus tremuloides Michx.) dominance. However, this potential depends on ill-defined constraints of aspen sexual regeneration under current climate. We created an ensemble of species distribution models for aspen seedling distribution following severe wildfire to define constraints on establishment. We recorded $P$. tremuloides seedling locations across a post-fire, post-blowdown landscape. We used 3 algorithms (Mahalanobis Typicalities, Multilayer Perceptron Artificial Neural Network, and MaxEnt) to create spatial distribution models for aspen seedlings and to define constraints. Each model performed with high accuracy and was incorporated into an ensemble model, which performed with the highest overall accuracy of all the models. Populus tremuloides seedling distribution is constrained primarily by proximity to unburned aspen forest and annual temperature ranges, and secondarily by light availability, summer precipitation, and fire severity. Based on model predictions and validation data, $P$. tremuloides seedling regeneration is viable throughout $54 \%$ of the post-fire landscape, $97 \%$ of which was previously conifer-dominated. Aspen are less susceptible to many climatically-sensitive disturbances (e.g. fire, beetle outbreak, wind disturbance), thus, aspen expansion represents an important adaptation to climate change. Continued aspen expansion into post-disturbance landscapes through sexual reproduction at the level suggested by these results would represent an important adaptation to climate change and would confer adaptive forest resilience by maintaining forest cover, but would also alter future disturbance regimes, biodiversity, and ecosystem services.
\end{abstract}

\section{Introduction}

Ecosystem function and resilience during a time of directional climate change are contingent on regeneration of plant communities. Plant communities are altered through disturbance and regeneration, processes that are in turn influenced by existing community structure and composition (Sousa, 1984; White and Pickett, 1985; Turner, 2010). The frequency and severity of fire, blowdown, and insect outbreaks (among other disturbances) are increasing in many temperate ecosystems due to climate change (Dale et al., 2001; Westerling et al., 2006; Allen, 2007; Evangelista et al., 2011; Siedl and Rammer, 2016), selecting for communities that can quickly regenerate during short intervals between disturbances or after severe disturbances (White, 1979;
Buma and Wessman, 2011). Communities that are no longer resilient under altered conditions may cross tipping points (Keeley et al., 1999; Gunderson, 2000), manifest as a shift to an alternate stable state following a large disturbance (Franklin, 1992; Turner et al., 1993). For example, subalpine forests of the interior western United States that are adapted to large, infrequent fires replenish the seed bank in a timeframe appropriate for the disturbance regimes of their evolutionary history, but in some cases a recent shortening of intervals between severe fires has compromised resilience and resulted in conversion to non-forest due to a lack of seed bank and post-fire regeneration (Buma et al., 2013; Harvey et al., 2013). The implications of shifting disturbance regimes on the resilience of forest ecosystems hinge on post-disturbance regeneration under altered climate conditions.

\footnotetext{
* Corresponding author at: Kilauea Field Station, 344 Crater Rim Drive, Volcano, HI 96718, USA.

E-mail address: ngill@clarku.edu (N.S. Gill).
} 
Altered climate may not only lead to transitions to non-forest, but also from one forest type to another, the latter potentially representing adaptive resilience. Such shifts in forest type are partly a function of stand-level species composition at the time of disturbance and the success of species-specific regeneration strategies under novel climate. In recent decades, gymnosperm spruce, fir, and pine species, which together dominate the subalpine forests of western North America, have been severely affected by a host of individual and interacting disturbances, especially wildfires, insect outbreaks, and wind storms (Veblen et al., 1991, 1994; Eisenhart and Veblen, 2000; Baker et al., 2002; Kulakowski and Veblen, 2002, 2006, 2007; Bigler et al., 2005). Although such disturbances have long shaped these ecosystems, disturbance frequency, intensity, and size have been increasing (Westerling et al., 2006; Evangelista et al., 2011). In contrast to conifers, the angiosperm quaking aspen (Populus tremuloides Michx.) is less likely to experience high mortality from most disturbances and has multiple regeneration strategies that may confer resilience against changing environmental conditions, setting the stage for a disturbancemediated change in forest type, potentially over large areas (Kulakowski and Veblen, 2002; Kulakowski et al., 2003; Buma and Wessman, 2012; Kulakowski et al., 2013a; Yang et al., 2015).

Populus tremuloides is the most widely distributed tree species in North America and performs many important ecological functions (Romme et al., 2001; Rogers et al., 2014; Rogers, 2015; Krasnow and Stephens, 2015). Populus tremuloides trees promote biodiversity, act as firebreaks, and provide many ecosystem services (Chong et al., 2001; Chong and Stohlgred, 2007; Zeigenfuss et al., 2008; Buck and St. Clair, 2012). Despite its broad niche, $P$. tremuloides has undergone extensive, rapid mortality in some parts of its range (Hogg et al., 2008; Worrall et al., 2010; Hanna and Kulakowski, 2012). In other parts, it has become dominant in post-disturbance areas previously dominated by conifers (Smith et al., 2011; Kulakowski et al., 2013 b). Broad-scale models of $P$. tremuloides distribution and its environmental constraints have predicted both a shifting and a shrinking of its range in the near future (Iverson and Prasad, 1998; Gustafson et al., 2003; Rehfeldt et al., 2009). Populus tremuloides dominance on the landscape has fluctuated over centuries in response to large, infrequent disturbances (Kulakowski et al., 2004, 2006) and climate (Morelli and Carr, 2011). Thus, some observed declines in aspen dominance may be normal and do not necessarily represent a net loss of aspen over the long term or broad spatial scales (Kulakowski et al., 2004, 2006, 2013a; Brown et al., 2006; Rogers et al., 2014). However, recent climate trends have clearly driven some $P$. tremuloides mortality (Hogg et al., 2008; Worrall et al., 2010; Hanna and Kulakowski, 2012). There is no consensus as to how the cumulative effects of range expansion and increasing mortality of $P$. tremuloides in North America are balancing out (Rogers et al., 2013). Spatial modelling at the landscape scale can provide important insights into these issues (Yang et al., 2015).

In northern Colorado, conifer regeneration was sparse following the large, severe Mt. Zirkel wildfire of 2002 where fire was preceded by an extensive blowdown in 1997, but much of the same area exhibited increased $P$. tremuloides following the 2002 fires (Kulakowski et al., 2013b). Kulakowski et al. (2013b) did not distinguish P. tremuloides seedling regeneration from vegetative resprouting, thus it was not clear whether new aspen individuals established across the landscape, or whether aspen that existed before the fire were simply resprouting. Another study in the same fire complex found ample regeneration of $P$. tremuloides from seed in areas of high fire severity (Buma and Wessman, 2012), but did not examine its spatial distribution across the burned area. This leaves unanswered the questions of whether and to what extent $P$. tremuloides may be expanding its range through seedling establishment after compounded disturbances. It has been suggested that a vast majority of aspen stands in the U.S. Intermountain West have persisted through asexual vegetative resprouting with little to no seedling regeneration for thousands of years (Barnes, 1966; Einspahr and Winton, 1976; Cook, 1983; Mitton and Grant, 1996). However, in recent years, episodes of $P$. tremuloides seedling establishment have been confirmed in various regions of Rocky Mountain subalpine forests, bringing the rarity of these events into question (Peterson and Peterson, 1992; Kay, 1993; Romme et al., 1997, 2001, 2005; Landhäusser et al., 2010; Long and Mock, 2012; Kulakowski et al., 2013b). The 2002 Mt. Zirkel fire in northwestern Colorado provides an opportunity to examine the environmental constraints on $P$. tremuloides seedling establishment in this region following large, severe wildfire and to examine the role of $P$. tremuloides sexual reproduction in adaptive forest resilience where compounded disturbances have compromised conifer regeneration strategies (Kulakowski et al., 2013b). Little is known about the constraining biophysical factors that influence this process across complex landscapes. Here we present an ensemble spatial distribution model that defines the environmental constraints on $P$. tremuloides seedling establishment and predicts the distribution of aspen seedlings following the large, severe fires of 2002.

While $P$. tremuloides sexual regeneration in the US Rocky Mountains is understood to be rare due to exacting temperature and moisture requirements (McDonough, 1979), we predict that these constraints are in fact sufficiently permissive to allow for widespread $P$. tremuloides recruitment across a landscape where conifer dominance is lost, thus potentially conferring adaptive forest resilience in response to warming climate and higher-frequency disturbance return intervals. Given adequate climatic and other biophysical conditions, P. tremuloides may, through its long-range dispersal range (McDonough, 1985; Howard, 1996; Long and Mock, 2012), role as a pioneer colonizer (Perala, 1990, Calder and St. Clair, 2012), and high stress tolerance (Lieffers et al., 2001; Buck and St. Clair, 2012), regenerate after compounded and otherwise intense disturbances where regeneration mechanisms of conifers have fallen short (Kulakowski et al., 2013b).

Hypotheses:

H1. We predict that post-fire $P$. tremuloides seedling establishment will be primarily constrained by low temperatures and lack of precipitation, which affect $P$. tremuloides seedlings' ability to compete with other regenerating vegetation.

H2. Despite these constraints, we predict that stand-replacing fires and compounded disturbances create low-competition conditions that are highly conducive to $P$. tremuloides regeneration from seed, including in areas beyond its pre-disturbance distribution, where forest regeneration has otherwise been compromised by compounded disturbance.

\section{Materials and methods}

\subsection{Study area}

The study area lies within Routt National Forest, straddling the western boundary of the Mt. Zirkel Wilderness in northern Colorado. The 6300-ha study area is defined as the area that burned at high-severity (stand-replacing according to field survey and Monitoring Trends in Burn Severity categories 4 and 5; MTBS, 2015) during the $2002 \mathrm{Mt}$. Zirkel Fire Complex west of the Continental Divide (Fig. 1). The study area has a continental climate and is dominated by Pinus contorta, Populus tremuloides, Picea engelmannii and Abies lasiocarpa. The region's upland soils are coarse-textured glacial deposits and Precambrian crystalline parent material, while valleys are derived from poorlydrained alluvial deposits (Snyder et al., 1987). The elevation of the study area ranges from 2400 to $3600 \mathrm{~m}$ above sea level. Average temperatures range from $-17.1{ }^{\circ} \mathrm{C}$ (January) to $28.1{ }^{\circ} \mathrm{C}$ (July). Mean annual precipitation is $60.2 \mathrm{~cm}$ of rain and $423 \mathrm{~cm}$ of snowfall (WRCC 2015, http://www.wrcc.dri.edu/).

Portions of the study area were affected by stand-replacing fires in 1879 and 1880 (Kulakowski and Veblen, 2002). Within and around the study area, a total of 12,354 ha of forest burned in the 2002 Mt. Zirkel Fire Complex, approximately 4,000 ha of which had been blown down 


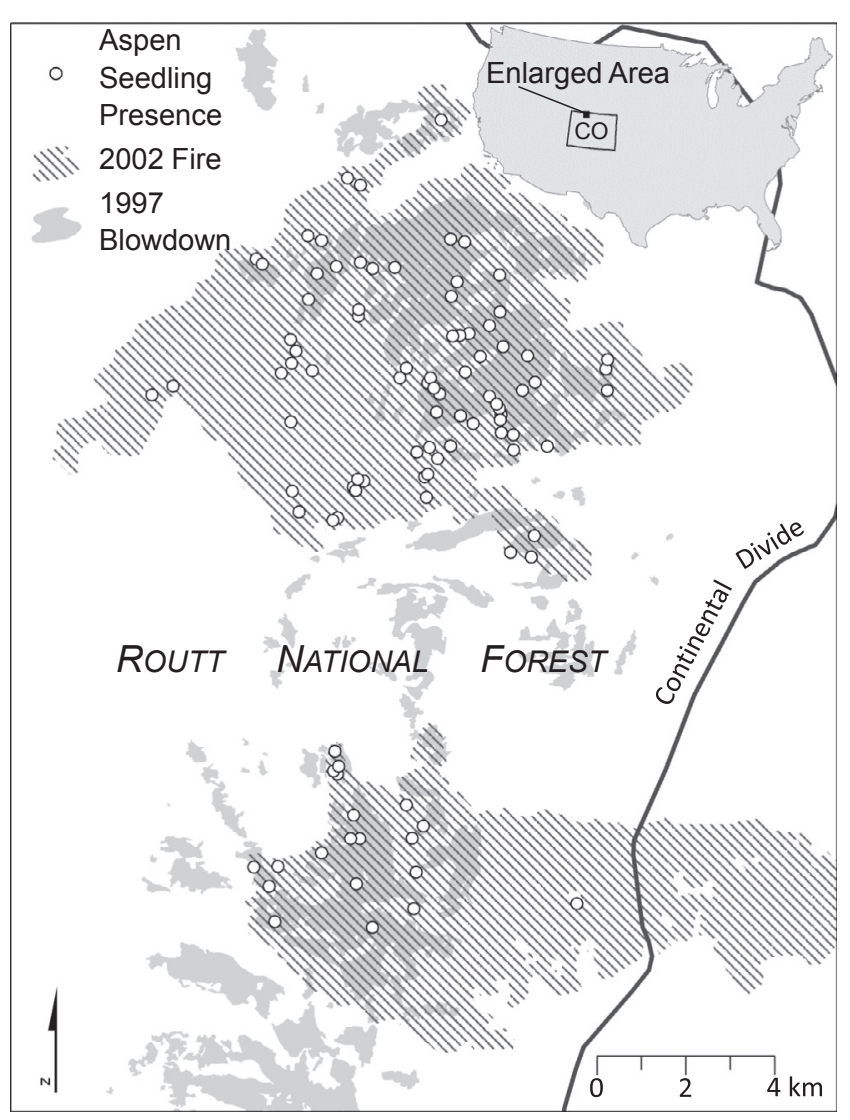

Fig. 1. The study area is the portion of Routt National Forest that burned at high severity (MTBS $\geq 4$ ) during the 2002 Mt. Zirkel Fire Complex west of the Continental Divide. Two-thirds of the study sites were incorporated as training data (white) while one-third were reserved for model validation (validation points not pictured here; see Fig. 3).

in a severe windstorm 5 years earlier.

\subsection{Data}

Populus tremuloides seedling presence data were collected at 102 sites in 2010. In 2015, 23 additional sites were added to the dataset to increase the breadth of environmental heterogeneity. Nine of the original sites were also revisited in 2015 to confirm persistence of $P$. tremuloides seedlings. Seedlings were counted in 20 or $225 \mathrm{~m}^{2}$ plots along 75-100 m long transects located in areas of homogeneous burn severity, topographic position, and pre-fire dominance, following the methods of Turner et al. (2003) and Buma and Wessman (2011). Plot sizes are variable because we have incorporated data from multiple, independent field surveys. We followed a stratified-random sampling design to select sites of different age, species composition, and type(s) of recent disturbance (blowdown, fire, or blowdown and fire). Seedlings were distinguished from ramets by their tapering below the root-shoot interface and aboveground morphology (Kay, 1993; Renkin et al., 1994). In very rare cases of uncertainty, seedlings were uprooted to definitively distinguish seedlings from ramets. All 125 sites had no vegetative root sprouts of $P$. tremuloides (determined based on no recent history of aspen presence and physical examination of all within-plot seedlings and ramets) and were included our analysis, while a small number of other sites were not included because vegetative ramets were present. Sites with no $P$. tremuloides were recorded as absence points, however, the number of these was small ( $n=9$; these are not part of the 125 sites reported in this study) and thus our models were based on pseudoabsence points, background points, or presence-only data rather than true absence data (see appendix for detailed descriptions).

Five explanatory biophysical factors were included in the models
(Table 1) using raster datasets represented with $30 \times 30 \mathrm{~m}$ pixels. These five variables were selected from numerous potential explanatory variables, including pre-fire stand structure (Kulakowski et al., 2013b), disturbance history over the last 300 years (Kulakowski et al., 2013b), and 19 bioclimatic factors (Hijmans et al., 2005) derived from PRISM temperature and precipitation data. PRISM data are the result of a variety of modelling techniques using a wide range of monitoring networks and sophisticated quality control measures (PRISM, 2004). Included in this monitoring network is a station that lies within the study area itself. All factors were tested for collinearity and redundant variables $(r>0.7)$ were removed. We selected five variables (described in the remainder of Section 2.2) based on results from tests of collinearity, preliminary model runs, and known environmental constraints of aspen distribution, growth and survival (McDonough, 1979; Howard, 1996; Rehfeldt et al., 2009).

\subsection{Distance from unburned seed source}

Because seed rain decreases with increased distance from seed source, distance from unburned aspen was incorporated into the models. Stands dominated by $P$. tremuloides that did not burn in the 2002 Mt. Zirkel Fire Complex were digitized in ArcGIS 10.3 from ArcGIS World Imagery (ESRI et al., 2016). The distance from the nearest unburned mature aspen-dominated stand was calculated in a GIS for each $30 \times 30 \mathrm{~m}$ cell within the study area.

\subsection{Summer precipitation}

Drier weather results in loss of turgor potential and germinability in P. tremuloides seed (McDonough, 1979). Because soil moisture could not be measured at a sufficiently fine spatial resolution across the entire 6300-ha, topographically complex landscape, summer precipitation was used as a proxy for water availability. PRISM temperature and precipitation 30-year normals from 1981 to 2010 (PRISM, 2004) were used to calculate the average amount of precipitation received during the warmest quarter of the year. These data were then resampled from $4 \times 4 \mathrm{~km}$ to $30 \times 30 \mathrm{~m}$ using cubic interpolation to capture fine-scale variability and to match the resolution of the other environmental variables used in the analysis.

\subsection{Annual range of temperature}

Aspen seed germination and establishment are temperature-dependent and sensitive to cyclical fluctuations (McDonough, 1979, 1985). PRISM temperature 30-year normals from 1981 to 2010 (PRISM, 2004) were used to calculate the average annual range of temperature. These data were resampled from $4 \times 4 \mathrm{~km}$ to $30 \times 30 \mathrm{~m}$ using cubic interpolation to estimate fine-scale variability and to match the resolution of other environmental variables.

\subsection{Topography-based solar radiation}

Trends in light availability have been used in plot-based studies and broad-scale models to predict the growth and distribution of $P$. tremuloides (Mittanck et al., 2014), and a stand in the light is more conducive to aspen seedling establishment (Morelli and Carr 2011; Wan et al., 2014). The total hours of direct solar radiation per year were calculated in the study area for each $30 \times 30 \mathrm{~m}$ cell based on a $30 \times 30 \mathrm{~m}$ Digital Elevation Model (USGS 2015) using the Area Solar Radiation analysis in ArcGIS 10.3. Differences in solar radiation due to latitude are quite small given the scale of the study area, but site solar radiation due to aspect and surrounding topography is quite variable given the rugged terrain of the landscape. 
Table 1

Data attributes.

\begin{tabular}{|c|c|c|c|}
\hline Data & Source & Spatial resolution & Time period \\
\hline Aspen seedling presence & In-situ observations & $15 \times 15 \mathrm{~m}$ or $2 \times 1 \mathrm{~m}$ aggregated to $75 \times 75 \mathrm{~m}$ & 2010, 2015 \\
\hline Distance from unburned seed source & Digitization of ESRI World Imagery & $30 \times 30 \mathrm{~m}$ & 2003 \\
\hline Summer precipitation & PRISM & $4 \times 4 \mathrm{~km}$ resampled to $30 \times 30 \mathrm{~m}$ & $1981-2010$ \\
\hline Annual temperature range & PRISM & $4 \times 4 \mathrm{~km}$ resampled to $30 \times 30 \mathrm{~m}$ & 1981-2010 \\
\hline Annual hours of sunlight & Derived from USGS DEM & $30 \times 30 \mathrm{~m}$ & N/A \\
\hline Burn Severity & MTBS & $30 \times 30 \mathrm{~m}$ & 2002 \\
\hline
\end{tabular}

\subsection{Burn severity}

High-severity burns, particularly when compounded with other disturbances, have been associated with complete organic soil reduction (Buma et al., 2014) and increased aspen dominance (Kulakowski et al., 2013b) in Rocky Mountain subalpine forests. Burn severity throughout the study area was determined based upon differenced Normalized Burn Ratio values (dNBR; Key et al., 2004) classified into ecologically significant classes according to imagery, in-situ plot data, and analyst experience by Monitoring Trends in Burn Severity for the Burn Ridge and Hinman fires of 2002 (MTBS, 2015). Only sites that burned in high-severity fires (classes 4 and 5) were included in the study area by design, thus the inclusion of burn severity class as a factor in the models represents a nuanced measure of the amount of green vegetation consumed in stand-replacing fire.

\subsection{Models}

The purpose of our modelling analysis was (1) to compare the utility of independent and ensemble modelling techniques for predicting $P$. tremuloides establishment (Araujo and New, 2007; Elith and Graham, 2009), and (2) to use the best-performing technique (whether independent or ensemble) to make ecologically relevant inferences on post-fire $P$. tremuloides recruitment. Three individual models were created to predict $P$. tremuloides seedling establishment following severe wildfire, each implementing a different algorithm (Mahalanobis Typicalities, Multilayer Perceptron Artificial Neural Network, and MaxEnt) to yield a balance of different approaches and parameter settings. Key differences between the three approaches include three representations of non-presence (presence-only, pseudo-absence, or background points) and the weighting of environmental factors (Table 2). Further details regarding each algorithm and the parameters used are given in the appendix. Each model was iterated and evaluated 5 times. All models used the same partitions of training, testing and environmental gradient data.

\subsection{Model evaluation}

Data reserved for model validation were used to calculate each model's overall accuracy and area under the receiver operating characteristic curve (hereafter AUC; Fielding and Bell, 1997; Phillips et al.,

Table 2

Model algorithm attributes. For more detail regarding model differences, refer to appendix.

\begin{tabular}{clll}
\hline Model algorithm & $\begin{array}{l}\text { Factor } \\
\text { weighting }\end{array}$ & $\begin{array}{l}\text { Observation data } \\
\text { type }\end{array}$ & Reference \\
\hline $\begin{array}{c}\text { Mahalanobis } \\
\text { Typicalities }\end{array}$ & Equal & Presence-only & Foody et al. (1992) \\
$\begin{array}{c}\text { Multilayer } \\
\text { Perceptron }\end{array}$ & Variable & $\begin{array}{l}\text { Presence- } \\
\text { pseudoabsence }\end{array}$ & $\begin{array}{l}\text { Atkinson et al. } \\
\text { (1997), Civco } \\
\text { (1993) }\end{array}$ \\
MaxEnt & Variable & $\begin{array}{l}\text { Presence- } \\
\text { background }\end{array}$ & $\begin{array}{l}\text { Phillips et al. } \\
\text { (2006a) }\end{array}$ \\
\hline
\end{tabular}

2006a, 2006b). For each model, we defined a confidence threshold as the value which included exactly $90 \%$ of the training presence points, thus maintaining omission errors below $10 \%$, following standard convention of species distribution modelling (Pearson et al., 2007; see also Gill and Sangermano, 2016). This threshold was used to determine overall accuracy and to delineate areas of high-confidence $P$. tremuloides seedling establishment for comparison against other area measures of the landscape (previous conifer dominance, fire severity, compounded blowdown and fire). Overall accuracy was calculated by dividing the number of correct testing data points (presence points above high-confidence threshold and background points below) by the total number of testing data points. AUC is a threshold-independent metric that evaluates model performance continuously across all levels of confidence in establishment (Phillips et al., 2006a). The use of AUC in evaluating species distribution models has been criticized for being sensitive to study area size, which both inflates AUC when background data are drawn from spatially extensive study areas and creates inconsistencies when comparing AUC values from study areas of vastly different sizes (Lobo et al., 2008; Jimenez-Valverde, 2011). For these reasons, we have kept our study area small and consistent for all models used and we calculated overall accuracy.

\subsection{Ensemble model creation}

Each of the 3 models surpassed the quality standard of average AUC $>0.7$ after 5 runs and was incorporated into the ensemble model (Araujo and New, 2007; Elith and Graham, 2009). The ensemble model was calculated by averaging the likelihood of $P$. tremuloides presence from the 3 models for each cell (Mermion et al., 2009), thus highlighting areas of model convergence and conferring confidence in modelled $P$. tremuloides recruitment. This ensemble model was then evaluated in the same manner as the other models.

\section{Results}

Each of the three algorithms- Mahalanobis Typicalities, Multilayer Perceptron Artificial Neural Network, and MaxEnt-yielded models that performed with high accuracy (Table 3). The MaxEnt model yielded the highest AUC and the ensemble model yielded the highest overall accuracy (Fig. 2; Table 3; see also Fig. A.1). Descriptions of individual model results are provided in the appendix.

MaxEnt-derived measures of variable importance indicated that the two environmental variables that were most important in accurately predicting aspen seedling establishment were distance from unburned

Table 3

Confidence thresholds and model performance. AUC is threshold-independent.

\begin{tabular}{llll}
\hline Model & $\begin{array}{l}90 \% \text { Training Presence } \\
\text { Confidence Threshold }\end{array}$ & $\begin{array}{l}\text { Overall } \\
\text { Accuracy }\end{array}$ & AUC \\
\hline $\begin{array}{llll}\text { Mahalanobis } \\
\quad \text { Typicalities }\end{array}$ & 0.42 & $76 \%$ & 0.774 \\
Multilayer Perceptron & 0.56 & $59 \%$ & 0.734 \\
MaxEnt & 0.42 & $75 \%$ & 0.848 \\
Ensemble & 0.47 & $77 \%$ & 0.803 \\
\hline
\end{tabular}



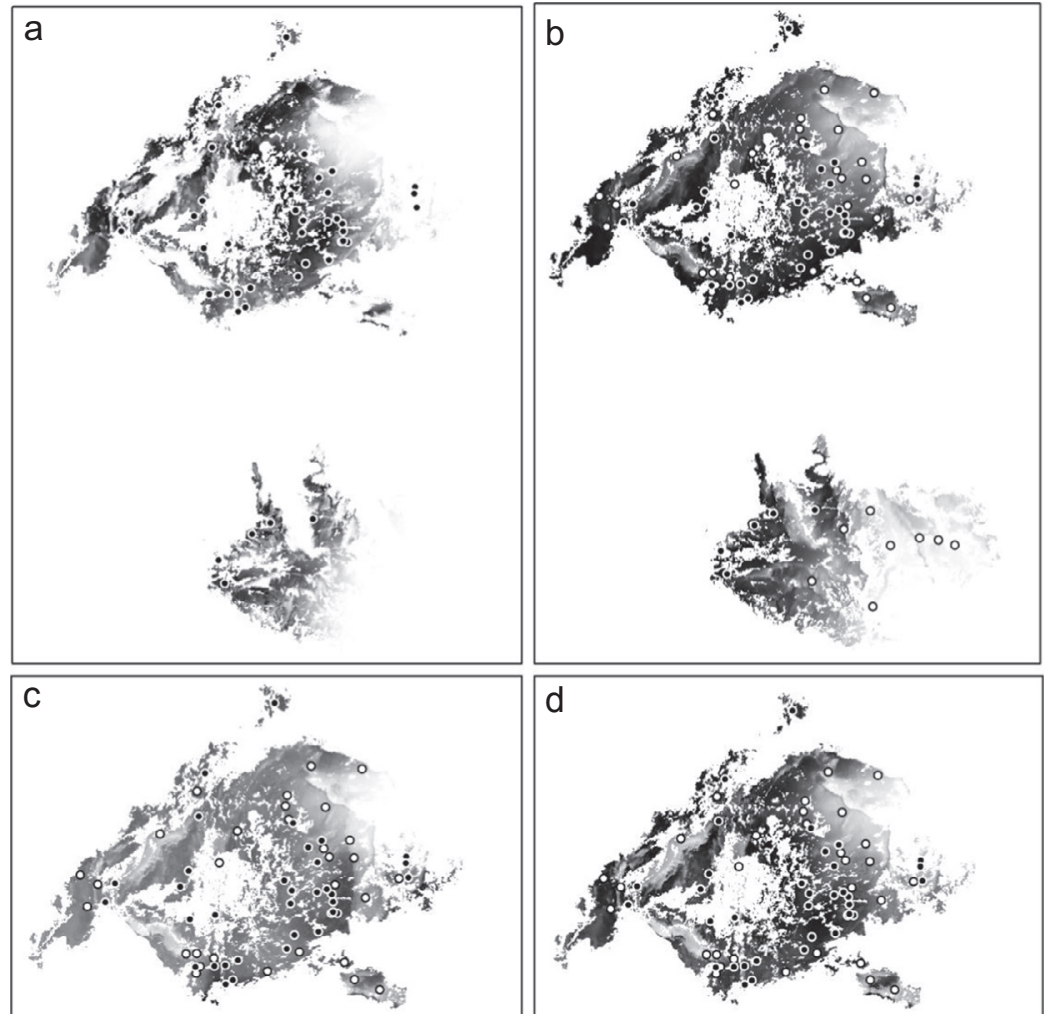

Testing Data

- Presence

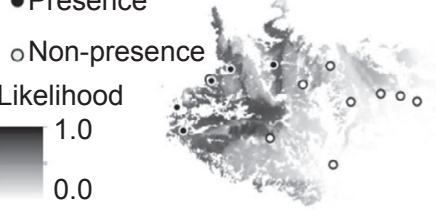

Fig. 2. Predicted aspen seedling establishment following stand-replacing wildfire according to four distribution models implementing the same data. Points represent testing data, which were held separate from the $67 \%$ of the dataset used for model training. A - Mahalanobis Typicalities, B Multilayer Perceptron ANN, C - MaxEnt, D - Ensemble.
Table 4

MaxEnt measures of variable importance for aspen recruitment.

\begin{tabular}{lll}
\hline Variable & Percent contribution & Permutation importance \\
\hline Distance from seed source & 36.6 & 27.6 \\
Annual temperature range & 26.3 & 31.1 \\
Annual hours of sunlight & 25.1 & 22.8 \\
Summer precipitation & 8.1 & 14.7 \\
Burn severity & 3.9 & 3.8 \\
\hline
\end{tabular}

seed source and annual range of temperature, whether measured by percent contribution or permutation importance (Table 4). Annual hours of sunlight also made important contributions to the MaxEnt model. The inclusion of summer precipitation improved the model's performance moderately, and burn severity (between classes 4 and 5) was of only slight importance to the model relative to the other factors.

Response curves of successful recruitment were as expected, based upon current understanding of aspen seedling establishment (Fig. 3). Modelled recruitment was highest close to unburned seed source. The predicted distance at which successful establishment drops below the $90 \%$ confidence threshold is $2.0 \mathrm{~km}$. The model predicted that seedlings are capable of establishing at distances beyond $2 \mathrm{~km}$ but only very rarely beyond $6 \mathrm{~km}$. Establishment was most consistently high at levels of moderate annual range in temperature $\left(33.5-37{ }^{\circ} \mathrm{C}\right.$ annual range), and was even higher in areas of extreme intra-annual temperature variability ( $>38.5{ }^{\circ} \mathrm{C}$ ), although model iterations exhibited greater divergence at this extreme range (Fig. 3). Establishment was more successful under increased hours of direct solar radiation, until > $4100 \mathrm{~h} / \mathrm{yr}$ (Fig. 3). Higher levels of summer precipitation were associated with high success of establishment, peaking at roughly $208 \mathrm{~mm}$ (Fig. 3), but this was complicated by the interaction of precipitation with the other factors (Fig. A.2). Lowest levels of summer precipitation $(<110 \mathrm{~mm})$ did not indicate especially low recruitment $(<0.4)$, but iteration differences at these lowest precipitation levels were high. Highest probabilities of establishment following stand-replacing fires (severity classes 4 and 5) were associated with burn severity category 5 , although differences between categories 4 and 5 were slight $(52 \%$ and $63 \%$, respectively).

The Ensemble Model performed with higher overall accuracy than any of the individual models, and had the second-highest AUC (Fig. 2; Table 3). In the northern Hinman Fire region, high confidence of successful establishment was located at lower elevations and along high, south-facing slopes in the east. The southern Burn Ridge region was characterized by patchy areas of mixed recruitment success in the west and mostly low success at the highest elevations and in the east (Fig.2d). In total, the Ensemble Model predicted with high-confidence that $54 \%$ of the landscape has successful $P$. tremuloides establishment. Over $58 \%$ of the area that was both blown down and burned exhibited high-confidence successful establishment (Fig. 4). Nearly all (97\%) of the area predicted by this model to have high-confidence seedling establishment was dominated by conifers before the 2002 fires. 

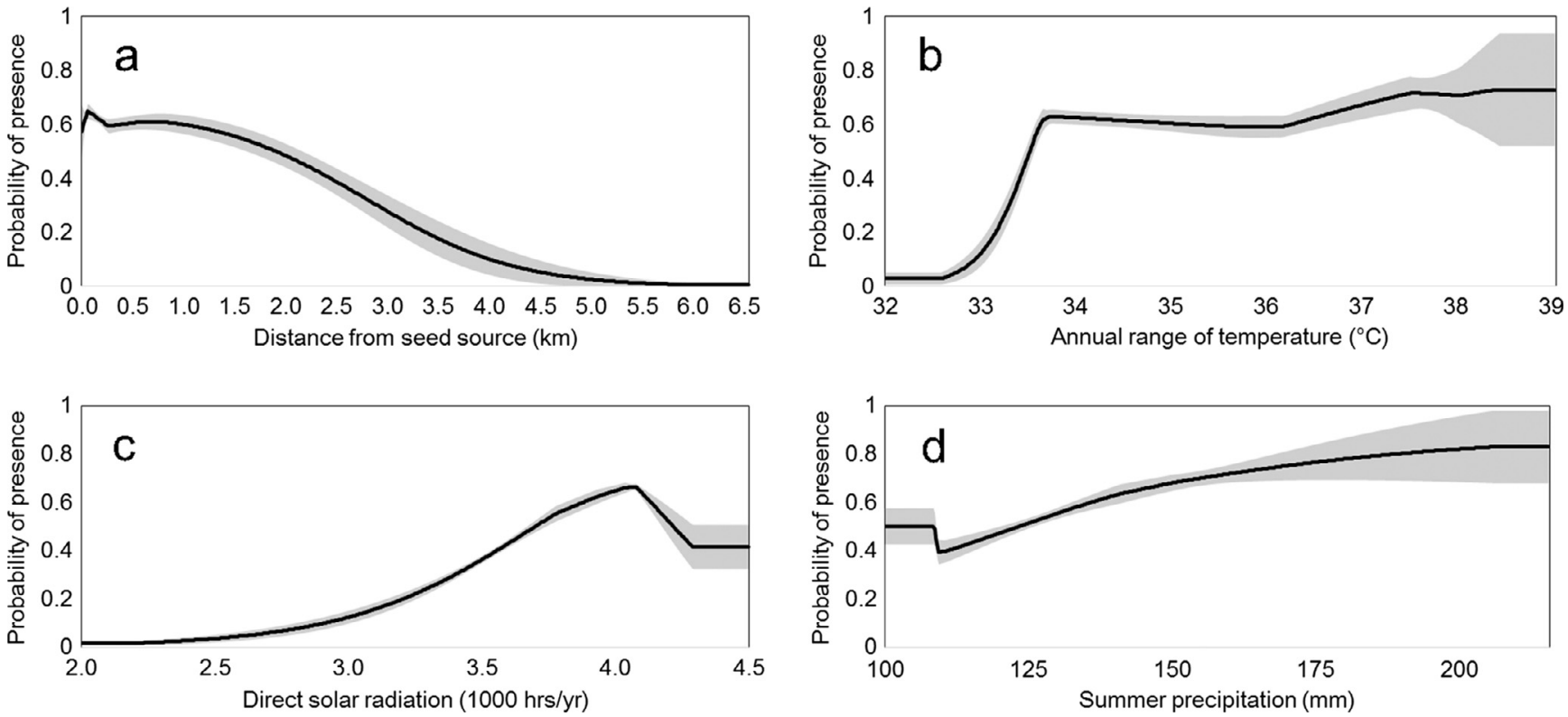

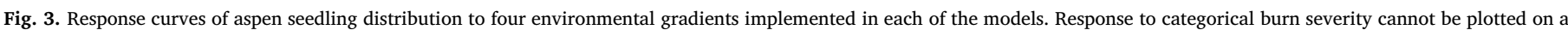
curve, but aspen seedlings had approximately $54 \%$ chance of establishment in either category (burn severity class 4 or 5 ). Shading depicts \pm 1 standard deviation.

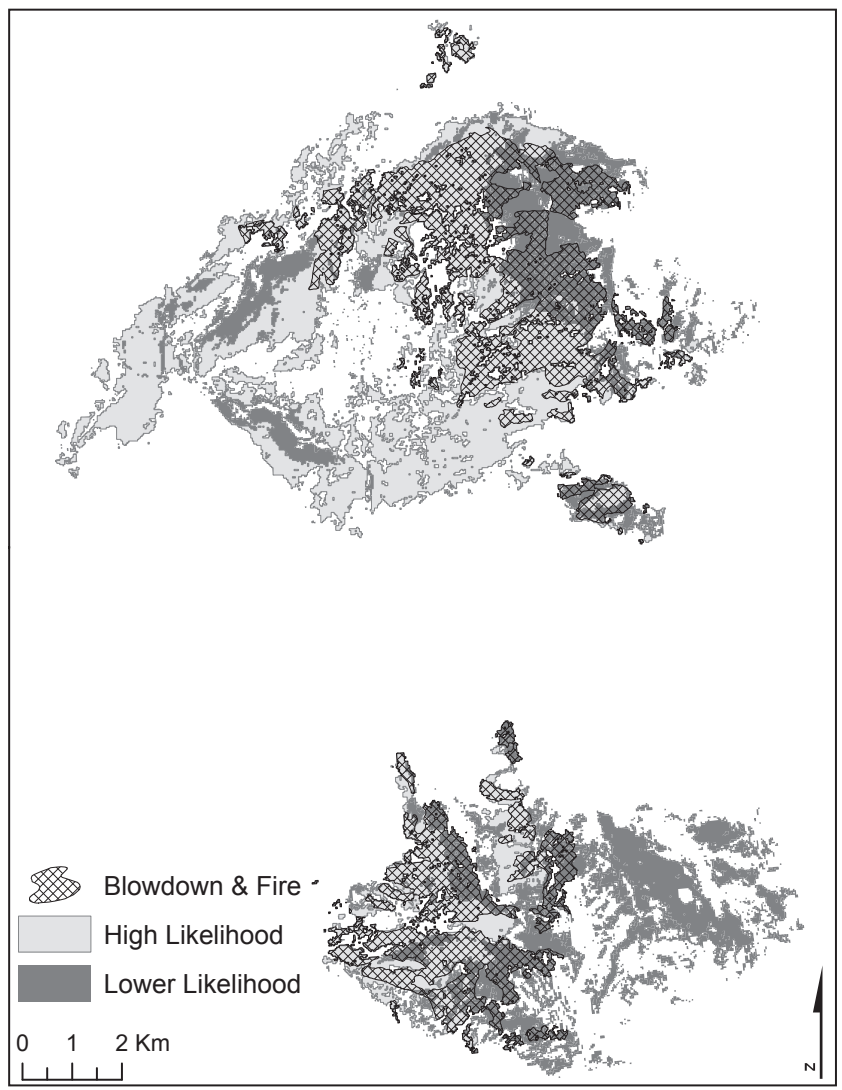

Fig. 4. The ensemble model predicted aspen establishment with high confidence (green/ light grey) across $54 \%$ of the severely-burned (stand-replacing, MTBS class 4-5) study area. Ninety-seven percent of this area of high-confidence modelled recruitment was conifer-dominated before 2002 , and it covers $58 \%$ of the area that was severely blown down (> 50\% mortality) before burning (compounded disturbance represented by crosshatch), the combination of which may inhibit conifer regeneration (Kulakowski et al., 2013b).

\section{Discussion}

\subsection{Major findings}

The current analysis suggests ongoing widespread potential conversion of forest type from conifer to $P$. tremuloides dominance following wildfires and compounded disturbances. Modelled presence of aspen seedlings across a heterogeneous subalpine landscape is constrained primarily by proximity to unburned mature $P$. tremuloides, range of annual temperatures, and light availability and is secondarily constrained by summer precipitation and burn severity. These constraints are consistent with previous findings that the establishment of P. tremuloides seedlings is limited by light (Warner and Kimball, 1972), dispersal range (Howard, 1996), temperature (Zasada and Viereck, 1975; McDonough, 1979), moisture (McDonough, 1979; Mitton, 1980; Howard, 1996), burn severity (Wan et al., 2014) and distance from unburned seed source (Howard, 1996)-although aspen seeds have the potential to disperse much greater distances under rare, optimal conditions, which has been shown probabilistically in our model (Fig.3a) and empirically (McDonough 1985; Long and Mock, 2012). Importantly, the present study shows that these constraints nevertheless allow widespread $P$. tremuloides seedling establishment following severe fire, possibly leading to an extensive conversion of forest type and exemplifying disturbance-induced adaptive resilience. Further research is needed to assess the net balance between this increase in post-disturbance aspen regeneration and predicted contraction of $P$. tremuloides range due to longer and more severe droughts (Worrall et al., 2008, 2013). This balance may be both temporally and spatially scale-dependent.

Our models offer a nuanced perspective of the niche of $P$. tremuloides in the US Intermountain West that is complementary to broader-scale models of its distribution. The use of broad-scale bioclimatic envelope models has brought about important strides toward understanding the factors contributing to aspen decline (Worral et al., 2013). However, consideration of community type (especially distinguishing sexual versus vegetative reproduction strategies) and stochastic disturbances has been largely missing from these models. The relative frequency of sexual vs. asexual reproduction influences long-term dominance and persistence of $P$. tremuloides at the landscape scale (Mock et al., 2008), partly determining whether communities are seral or stable (Calder and 
St. Clair, 2012; Rogers et al., 2014). The current study suggests that $P$. tremuloides can successfully regenerate from seed following stand-replacing fires across environmental conditions broad enough to be found throughout much of the post-fire subalpine landscape in the Rocky Mountains. Our data suggest that the area that is most conducive to $P$. tremuloides seedling establishment was almost entirely dominated by conifers before the 2002 wildfires. This broad niche of $P$. tremuloides seedling establishment also covers $58 \%$ of the forest that was blown down in 1997 and subsequently burned in 2002, in which compounded disturbances reduced conifer regeneration (Kulakowski et al., 2013b).

While additional research is needed to quantify the degree to which modelled seedling presence translates to realized colonization, the models presented in the current study demonstrate that a majority of the severely burned landscape is biophysically similar to those sites at which $P$. tremuloides seedlings were recorded. As regenerating aspen stands continue to develop to the point that they are spectrally distinguishable from the rest of the post-fire environment, it may become possible to remotely detect the area of realized colonization in coming years (Bergen and Dronova, 2007; Mittanck et al., 2014).

\subsection{Implications for future ecosystem function and management}

If newly established $P$. tremuloides persist under future climatic conditions, the landscape will remain in a forested state, but may shift from coniferous toward deciduous forest type, either temporarily (Calder and St. Clair, 2012) or as stable aspen forest (Rogers et al., 2014). This adaptive resilience would have important implications for ecosystem function and management, including biogeochemical cycling, disturbance regimes, and ecological services (Turner et al., 2003; Buma and Wessman, 2013; Rogers et al., 2014; Rogers, 2015). Subalpine $P$. tremuloides stands provide increased soil moisture, respiration, and nutrient concentrations compared to subalpine conifer stands and meadows (Buck and St. Clair, 2012), and can serve multiple functional purposes (Rogers et al., 2014). Stands dominated by P. tremuloides are less-susceptible to fire, blowdown, and insect outbreak than the Engelmann spruce, subalpine fir, and lodgepole pine stands that dominate subalpine forests in this region (van Wagner, 1977; Veblen et al., 2001; Kulakowski and Veblen, 2002, 2007; Kulakowski et al., 2003, 2013b). A possible broad-scale reduction in susceptibility to these disturbances due to increased $P$. tremuloides prevalence may serve as a negative feedback to the effect of warming temperatures on fire, beetle outbreak, and blowdown frequency and severity in these forests. Widespread seedling establishment of $P$. tremuloides increases genetic diversity within and among aspen stands, which could be critical to future expansion, persistence, or decline of aspen in the region (Stevens et al., 1999), and should be the focus of future research and management (Long and Mock, 2012).

\subsection{Limitations}

While our field data and landscape modelling of aspen seedling presence indicate potential conversion of forest types from seral to stable aspen (Rogers et al., 2014; Carter et al., 2017), we acknowledge several limitations to this study. First, the current analysis lacks finescale temporal sensitivity-monthly or annual temperature and precipitation variables may be more important in the early stages of seedling establishment than the multi-decadal climatic factors we evaluated (Hanna and Kulakowski, 2012; Hansen et al., 2016). Second, modelled recruitment represents some level between the fundamental and realized niche (Mittanck et al., 2014) of seedling establishment, and further work is needed to quantify the realized distribution (Araujo and Guisan, 2006). Third, as aspen is a widely distributed species with a broad variety of ecological roles and niches across its distribution (Rogers et al., 2014), generalizations to the broader range of $P$. tremuloides should be made cautiously (Elith and Leathwick, 2009). Fourth, although we recorded persistence of seedlings through 2015 at many sites used in this analysis, the persistence of aspen over the coming decades is uncertain and is contingent on a variety of factors, including suitable climatic conditions (Gill et al., in press). Finally, our analysis was based on five key explanatory variables that were identified in initial model runs as most influential on $P$. tremuloides seedling establishment. Two factors we did not consider in final models were pre-fire stand composition and disturbance history over the past centuries, both variables that Kulakowski et al. (2013b) found to influence P. tremuloides regeneration density (of combined seedling and ramet regeneration). Despite these limitations, the current research highlights that although compounded disturbances and unfavorable post-disturbance climate have compromised widespread conifer regeneration in subalpine forests, aspen appear to be regenerating successfully and potentially expanding their distribution (Kulakowski et al., 2013b;Yang et al., 2015; Carter et al., 2017).

\section{Conclusions}

While aspen seedling establishment has been thought to be unusual in the southern Rockies, this study shows that post-fire $P$. tremuloides regeneration from seed can be successful across broad biophysical settings, even where the resilience of other tree species is compromised. Indeed, our models predict $P$. tremuloides seedling presence with high confidence across more than half of the area burned in the high-severity fires of 2002, nearly all of which was dominated by conifers prior to the fires. This includes over half the area that was affected by compounded disturbances of 1997 blowdown and 2002 fire that inhibited conifer regeneration (Kulakowski et al., 2013b). If $P$. tremuloides regeneration persists where conifer regeneration has failed, it will serve as a mechanism for adaptive resilience and have major implications for community type conversion (Rogers et al., 2014) and future ecological dynamics, including disturbance regimes (Kulakowski et al., 2003; Kulakowski and Veblen 2007), hydrology, and nutrient cycling (Buck and St. Clair, 2012).

However, important questions remain. Will environmental conditions remain favorable for the regeneration and persistence of aspen? What feedbacks will result? Is this a rare window of opportunity (Mitton and Grant, 1996), or are these events not as rare as previously thought? Future research should pursue these questions and incorporate additional relevant factors, especially the role of climatic variability in successful aspen regeneration. Not only is the persistence of $P$. tremuloides important ecologically and economically (Frey et al., 2004), but understanding the trajectories of its distribution after fire is critical to managing for future disturbance. An increased proportion of forest dominated by $P$. tremuloides may lead to greater biodiversity and adaptive resilience against many disturbances that have been increasing in frequency and severity throughout subalpine forests of North America and elsewhere.

\section{Acknowledgements}

We acknowledge Nathan Mietkiewicz, Dan Jarvis, the field crews that assisted with data collection, and the USFS for providing access to field sites. We thank three anonymous referees who reviewed a previous draft of this manuscript. This research was supported by the National Science Foundation award 1262691 and NSF Graduate Research Fellowship 2015187717.

\section{Appendix A. Supplementary material}

Supplementary data associated with this article can be found, in the online version, at http://dx.doi.org/10.1016/j.foreco.2017.08.008. These data include Google maps of the most important areas described in this article. 


\section{References}

Allen, C.D., 2007. Cross-scale interactions among forest dieback fire, and erosion in northern New Mexico landscapes. Ecosystems 10, 797-808.

Araújo, M.B., Guisan, A., 2006. Five (or so) challenges for species distribution modeling. J. Biogeogr. 33, 1677-1688.

Araújo, M.B., New, M., 2007. Ensemble forecasting of species distributions. Trends Ecol. Evolut. 22, 42-47.

Atkinson, P.M., Tatnall, A.R.L., 1997. Neural networks in remote sensing. Int. J. Remote Sens. 18, 699-709.

Baker, W.L., Flaherty, P.H., Lindemann, J.D., Veblen, T.T., Eisenhart, K.S., Kulakowski, D.W., 2002. Effect of vegetation on the impact of a severe blowdown in the southern Rocky Mountains, USA. For. Ecol. Manag. 168, 63-75.

Barnes, B.V., 1966. The clonal growth habit of American aspens. Ecology 47, 439-447.

Bergen, K.M., Dronova, I., 2007. Observing succession on aspen-dominated landscapes using a remote sensing-ecosystem approach. Landscape Ecol. 22, 1395-1410.

Bigler, C., Kulakowski, D., Veblen, T.T., 2005. Multiple disturbance interactions and drought influence fire severity in Rocky Mountain subalpine forests. Ecology 86, 3018-3029.

Brown, K., Hansen, A.J., Keane, R.E., Graumlich, L.J., 2006. Complex interactions shaping aspen dynamics in the Greater Yellowstone Ecosystem. Landscape Ecol. 21, 933-951.

Buck, J., St. Clair, S.B., 2012. Aspen increase soil moisture, nutrients, organic matter and respiration in Rocky Mountain forest communities. PLoS ONE 7, e52369. http://dx. doi.org/10.1371/journal.pone.0052369.

Buma, B., Wessman, C.A., 2011. Disturbance interactions can impact resilience mechanisms of forests. Ecosphere 2, 1-13.

Buma, B., Wessman, C.A., 2012. Differential species responses to compounded perturbations and implications for landscape heterogeneity and resilience. For. Ecol. Manag. 266, 25-33.

Buma, B., Wessman, C.A., 2013. Forest resilience, climate change, and opportunities for adaptation: a specific case of a general problem. For. Ecol. Manag. 306, 216-225.

Buma, B., Brown, C., Donato, D., Fontaine, J.B., Johnstone, J.F., 2013. The impacts of changing climate regimes on serotinous plant populations and communities. BioScience 63, 866-876.

Buma, B., Poore, B., Wessman, C.A., 2014. Interacting disturbances and their effect on carbon, charcoal, and further implications for carbon sequestration in forests. Ecosystems 17, 947-959.

Calder, W.J., St. Clair, S.B., 2012. Facilitation drives mortality patterns along succession gradients of aspen-conifer forests. Ecosphere 3, 1-11.

Carter, V.A., Brunelle, A., Minckley, T.A., Shaw, J.D., DeRose, R.J., Brewer, S., 2017. Climate variability and fire effects on quaking aspen in the central Rocky Mountains, USA. J. Biogeogr. 44, 1280-1293.

Chong, G.W., Stohlgren, T.J., 2007. Species-area curves indicate habitats' contributions to regional biodiversity. Ecol. Indic. 387-395.

Chong, G.W., Simonson, S.E., Stohlgren, T.J., Kalkhan, M.A., 2001. Biodiversity: aspen stands have the lead, but will nonnative species take over? Sustaining aspen in western landscapes (comp. by Shepperd, W.D., Binkley, D., Bartos, D.L., Stohlgren, T. J., Eskew, L.G.), 261-272. USDA Forest Service, Rocky Mountain Research Station, Proceedings, RMRS-P-18.

Civco, D.L., 1993. Artificial neural networks for land cover classification and mapping. Int. J. Geogr. Inf. Sci. 7, 173-186.

Cook, R.E., 1983. Clonal plant populations. Am. Sci. 71, 244-253.

Dale, V.H., Joyce, L.A., McNulty, S., Neilson, R.P., Ayres, M.P., Flannigan, M.D., Hanson, P.J., Irland, L.C., Lugo, A.E., Peterson, C.J., Simberloff, D., Swanson, F.J., Stocks, B.J., Wotton, B.M., 2001. Climate change and forest disturbances. BioScience 51, 723-734.

Einspahr, D.W., Winton, L.L., 1976. Genetics of quaking aspen. USDA Forest Service Research Paper WO-25.

Eisenhart, K.S., Veblen, T.T., 2000. Dendrochronological detection of spruce bark beetle outbreaks in northwestern Colorado. Can. J. For. Res. 30, 1788-1798.

Elith, J., Graham, C.H., 2009. Do they? How do they? WHY do they differ? On finding reasons for differing performances of species distribution models. Ecography 32 66-77.

Elith, J., Leathwick, J., 2009. Species distribution models: ecological explanation and prediction across space and time. Annu. Rev. Ecol. Evol. Syst. 40, 677-697.

ESRI, DigitalGlobe, GeoEye, i-cubed, USDA FSA, USGS, AEX, Getmapping, Aerogrid, IGN, IGP, Swisstopo, the GIS User Community, 2016. World Imagery.

Evangelista, P.H., Kumar, S., Stohlgren, T.J., Young, N.E., 2011. Assessing forest vulnerability and the potential distribution of pine beetles under current and future climate scenarios in the Interior West of the US. For. Ecol. Manag. 262, 307-316.

Frey, B.R., Leiffers, V.J., Hogg, E.H., Landhausser, S.M., 2004. Predicting landscape patterns of aspen dieback: mechanisms and knowledge gaps. Can. J. Forest Res. 34, 1379-1390.

Fielding, A.H., Bell, J.F., 1997. A review for the assessment of prediction errors in con servation presence/absence models. Environ. Conserv. 24, 38-49.

Foody, G.M., Campbell, N.A., Trodd, N.M., Wood, T.F., 1992. Derivation and applications of probabilistic measures of class membership from the maximum likelihood classification. Photogramm. Eng. Remote Sensing 58, 1335-1341.

Franklin, J.F., 1992. Effects of global climatic change on forests in northwestern North America. In: Peters, R.L., Lovejoy, T.E. (Eds.), The consequences of the greenhouse effect for biological diversity. Yale University Press, New Haven, CT, USA, pp. 244-257

Gill, N.S., Sangermano, F., 2016. Africanized honeybee habitat suitability: a comparison between models for southern Utah and southern California. Appl. Geogr. 76, 14-21.
Gill, N.S., Veblen, T.T., Pickett, S.T.A., Jarvis, D., Kulakowski, D., (in press). Is initial postdisturbance regeneration indicative of longer-term trajectories? Ecosphere. DOI:10. 1002/ecs2.1924.

Gustafson, E.J., Lietz, S.M., Wright, J.L., 2003. Predicting the spatial distribution of aspen growth potential in the Upper Great Lakes Region. For. Sci. 49, 499-508.

Gunderson, L.H., 2000. Ecological resilience-in theory and application. Annu. Rev. Ecol. Evol. Syst. 21, 425-439.

Hanna, P., Kulakowski, D., 2012. The influences of climate on aspen dieback. For. Ecol. Manag. 274, 91-98.

Hansen, W.D., Romme, W.H., Ba, A., Turner, M.G., 2016. Shifting ecological filters mediate post-fire expansion of seedling aspen (Populus tremuloides) in Yellowstone. For. Ecol. Manag. 362, 218-230.

Harvey, B.J., Donato, D.C., Turner, M.G., 2013. Burn me twice, shame on who? Interactions between successive forest fires across a temperate mountain region. Ecology 97, 2272-2282.

Hijmans, R.J., Cameron, S.E., Parra, J.L., Jones, P.G., Jarvis, A., 2005. Very high resolution interpolated climate surfaces for global land areas. Int. J. Climatol. 25, 1965-1978.

Hogg, E.H., Brandt, J.P., Michaelian, M., 2008. Impacts of a regional drought on the productivity, dieback, and biomass of western Canadian aspen forests. Can. J. For. Res. 38, 1373-1384.

Howard, J.L., 1996. Populus tremuloides. In: Fire effects information system. USDA, Forest Service, Rocky Mountain Research Station, Fire Sciences Laboratory.

Iverson, L.R., Prasad, A.M., 1998. Predicting abundance of 80 tree species following climate change in the eastern United States. Ecol. Monogr. 68, 465-485.

Jimenez-Valverde, A., 2011. Insights into the area under the receiver operating characteristic curve (AUC) as a discrimination measure in species distribution modeling. Global Ecol. Biogeogr. 21, 498-507.

Kay, C.E., 1993. Aspen seedlings in recently burned areas of Grand Teton and Yellowstone National Parks. Northwest Sci. 67, 94-104.

Keeley, J.E., Ne'eman, G., Fotheringham, C.J., 1999. Immaturity risk in a fire-dependent pine. J. Mediterranean Ecol. 1, 41-48.

Key, C.H., Benson, N.C., 2004. Landscape assessment: ground measure of severity, the composite burn index; and remote sensing of severity, the normalized burn ratio. In: Lutes, D.C., Keane, R.E., Caratti, J.F., Key, C.H., Benson, N.C., Gangi, L.J. (Eds.), Firemon: Fire Effects Monitoring and Inventory System. USDA Forest Service General Technical Report RMRS-GTR-XXX.

Krasnow, K.D., Stephens, S.L., 2015. Evolving paradigms of aspen ecology and management: impacts of stand condition and fire severity on vegetation dynamics. Ecosphere 6, 1-16.

Kulakowski, D., Veblen, T.T., 2002. Influences of fire history and topography on the pattern of a severe wind blowdown in a Colorado subalpine forest. J. Ecol. 90, 806-819.

Kulakowski, D., Veblen, T.T., 2006. The effect of fires on susceptibility of subalpine forests to a 19th century spruce beetle outbreak in western Colorado. Can. J. For. Res. 36, 2974-2982.

Kulakowski, D., Veblen, T.T., 2007. Effect of prior disturbances on the extent and severity of wildfire in Colorado subalpine forests. Ecology 88, 759-769.

Kulakowski, D., Veblen, T.T., Bebi, P., 2003. Effects of fire and spruce beetle outbreak legacies on the disturbance regime of a subalpine forest in Colorado. J. Biogeogr. 30, 1445-1456.

Kulakowski, D., Veblen, T.T., Drinkwater, S., 2004. The persistence of quaking aspen (Populus tremuloides) in the Grand Mesa Area, Colorado. Ecol. Appl. 14, 1603-1614.

Kulakowski, D., Veblen, T.T., Kurzel, B.P., 2006. Influences of infrequent fire, elevation and pre-fire vegetation on the persistence of quaking aspen (Populus tremuloides Michx.) in the Flat Tops area, Colorado. USA. J. Biogeogr. 33, 1397-1413.

Kulakowski, D., Kaye, M.W., Kashian, D.M., 2013a. Long-term aspen cover change in the western US. For. Ecol. Manag. 299, 52-59.

Kulakowski, D., Matthews, C., Jarvis, D., Veblen, T.T., 2013b. Compounded disturbances in sub-alpine forests in western Colorado favour future dominance by quaking aspen (Populus tremuloides). J. Veg. Sci. 24, 168-176.

Landhäusser, S.M., Deshaies, D., Lieffers, V.J., 2010. Disturbance facilitates rapid range expansion of aspen into higher elevations of the Rocky Mountains under a warming climate. J. Biogeogr. 37, 68-76.

Lieffers, V.J., Landhausser, S.M., Hogg, E.H., 2001. Is the wide distribution of aspen a result of its stress tolerance? In: Shepperd, W.D., Binkley, D., Bartos, D.L., Stohlgren, T., Eskew, L.G., (comps.) Sustaining aspen in western landscapes: Symposium proceedings; 13-15 June 2000; Grand Junction, CO. Proceedings RMRS-P-18. Fort Collins, CO: USDA, Forest Service, Rocky Mountain Research Station, pp. 311-324.

Lobo, J.M., 2008. More complex distribution models or more representative data? Biodiver. Inform. 5, 14-19.

Long, J.N., Mock, K., 2012. Changing perspectives on regeneration ecology and genetic diversity in western quaking aspen: implications for silviculture. Can. J. Forest Res. 42, 2011-2021.

McDonough, W.T., 1979. Quaking aspen-seed germination and early seedling growth. INT-234. Ogden, UT: USDA, Forest Service, Intermountain Forest and Range Experiment Station.

McDonough, W.T., 1985. Sexual reproduction, seeds and seedlings. In: Aspen: ecology and management in the western United States (ed. by DeByle, N.V., Winokur, R.P.) 25-33, USDA General Technical Report RM- 119.

Marmion, M., Parviainen, M., Luoto, M., Heikkinen, R.K., Thuiller, W., 2009. Evaluation of consensus methods in predictive species distribution modeling. Divers. Distrib. 15, 59-69.

Mittanck, C.M., Rogers, P.C., Ramsey, R.D., Bartos, D.L., Ryel, R.J., 2014. Exploring succession within aspen communities using a habitat-based modeling approach. Ecol. Model. 288, 203-212. 
Mitton, J., Grant, M., 1980. Observations on the Ecology and Evolution of Quaking Aspen, Populus tremuloides, in the Colorado Front Range. Am. J. Bot. 67, 202-209.

Mitton, J.B., Grant, M.C., 1996. Genetic variation and the natural history of quaking aspen. BioScience 46, 25-31.

Mock, K.E., Rowe, C.A., Hooten, M.B., Dewoody, J., Hipkins, V.D., 2008. Clonal dynamics in western North American aspen (Populus tremuloides). Mol. Ecol. 17, 4827-4844.

Morelli, T.L., Carr, S.C., 2011. A review of the potential effects of climate change on quaking aspen (Populus tremuloides) in the Western United States and a new tool for surveying aspen decline. USDA Forest Service Pacific Southwest Research Station, General Technical Report PSW-GTR-235.

MTBS Data Access: Fire Level Geospatial Data. MTBS Project (USDA Forest Service/U.S. Geological Survey). Accessed 2015. http://mtbs.gov/data/individualfiredata.html.

Pearson, R.G., Raxworthy, C.J., Nakamura, M., Townsend Peterson, A., 2007. Predicting species distributions from small numbers of occurrence records: a test case using cryptic geckos in Madagascar. J. Biogeogr. 34, 102-117.

Perala, D.A., 1990. Populus tremuloides Michx. quaking aspen. In: Burns, R.M., Honkala, B. H., technical coordinators. Silvics of North America: Volume 2, Hardwoods. Agriculture Handbook 654. Washington, DC: USDA, Forest Service, pp. 555-569.

Peterson, E.B., Peterson, N.M., 1992. Ecology, management, and use of aspen and balsam poplar in the prairie provinces, Canada. NTIS Special Report 1 prepared for Forestry Canada Northwest Region, Northern Forestry Centre, Edmonton, AB, Canada.

Phillips, S.J., Anderson, R.P., Schapire, R.E., 2006a. Maximum entropy modeling of species geographic distributions. Ecol. Model. 190, 231-259.

Phillips, S.J., Dudík, M., Schapire, R.E., 2006b. A maximum entropy approach to species distribution modeling. In: Proceedings of the Twenty-First International Conference on Machine Learning, pp. 655-662.

PRISM Climate Group, 2004. Oregon State University, http://prism.oregonstate.edu.

Rehfeldt, G.E., Ferguson, D.E., Crookston, N.L., 2009. Aspen, climate, and sudden decline in Western USA. For. Ecol. Manag. 258, 2353-2364.

Renkin, R., Despain, D., 1994. Suckering in burned aspen as related to above-ground and below-ground biomass. In: Despain, D.G. (Ed.), Plants and their environments: proceedings of the 1st biennial scientific conference on the Greater Yellowstone Ecosystem (ed. by Despain, D.G.), 341-343, Yellowstone National Park. Tech. Rep. NPS/NRYELL/NRTR-93/XX. Denver, CO: US DOI, NPS, Rocky Mountain Region, Yellowstone National Park.

Rogers, P.C., Eisenberg, C., St. Clair, S.B., 2013. Resilience in Quaking Aspen: recent advances and future needs. For. Ecol. Manag. 299, 1-5.

Rogers, P.C., Landhäusser, S.M., Pinno, B.D., Ryel, R.J., 2014. A Functional Framework for Improved Management of Western North American Aspen (Populus tremuloides Michx.). Forest Sci. 60, 345-359.

Rogers, P.C., 2015. Building resilience into quaking aspen management. Aspen Bibliography, Paper, pp. 7312.

Romme, W.H., Turner, M.G., Gardner, R.H., Hargrove, W.W., Tuskan, G.A., Despain, D.G., Renkin, R.A., 1997. A rare episode of sexual reproduction in aspen. Nat. Area. J. 17, $17-25$.

Romme, W.H., Floyd-Hanna, L., Hanna, D.D., Bartlett, E., 2001. Aspen's ecological role in the West. USDA Forest Service Proceedings RMRS-P-18.

Romme, W.H., Turner, M.G., Tuskan, G.A., Reed, R.A., 2005. Establishment, persistence, and growth of aspen (Populus tremuloides) seedlings in Yellowstone National Park Ecology 86, 404-418.

Seidl, R., Rammer, W., 2016. Climate change amplifies the interactions between wind and bark beetle disturbances in forest landscapes. Landscape Ecol. http://dx.doi.org/10. 1007/s10980-016-0396-4.

Smith, E.A., O'Loughlin, D., Buck, J.R., St. Clair, S.B., 2011. The influences of conifer succession, physiographic conditions and herbivory on quaking aspen regeneration after fire. For. Ecol. Manag. 262, 325-330.

Snyder, G.L., Patten, L.L., Daniels, J.J., 1987. Mineral resources of the Mount Zirkel Wilderness and northern Park Range vicinity, Jackson and Routt counties, Colorado. Bulletin 1554, U.S. Geologica Survey, Washington D.C., USA.

Sousa, W.P., 1984. The role of disturbance in natural communities. Annu. Rev. Ecol. Syst. $15,353-391$.

Stevens, M.T., Turner, M.G., Tuskan, G.A., Romme, W.H., Gunter, L.E., Waller, D.M., 1999. Genetic variation in post-fire aspen seedlings in Yellowstone National Park. Mol. Ecol. 8, 1769-1780.

Turner, M.G., 2010. Disturbance and landscape dynamics in a changing world. Ecology 91, 2833-2849.

Turner, M.G., Romme, W.H., Reed, R.A., Tuskan, G.A., 2003. Post-fire aspen seedling recruitment across the Yellowstone (USA) Landscape. Landscape Ecol. 18, 127-140.

Turner, M.G., Romme, W.H., Gardner, R.H., O’Neill, R.V., Kratz, T.K., 1993. A revised concept of landscape equilibrium: disturbance and stability on scaled landscapes. Landscape Ecol. 8, 213-227.

van Wagner, C.E., 1977. Conditions for the start and spread of crown fires. Can. J. Forest Res. 7, 23-34.

Veblen, T.T., Hadley, K.S., Nel, E.M., Kitzberger, T., Reid, M., Villalba, R., 1994. Disturbance regime and disturbance interactions in a Rocky Mountain subalpine forest. J. Ecol. 82, 125-135.

Veblen, T.T., Hadley, K.S., Reid, M.S., Rebertus, A.J., 1991. The response of subalpine forests to spruce beetle outbreak in Colorado. Ecology 72, 213-231.

Veblen, T.T., Kulakowski, D., Eisenhart, K.S., Baker, W.L., 2001. Subalpine forest damage from a severe windstorm in Northern Colorado. Can. J. Forest Res. 31, 2089-2097.

Wan, H.Y., Rhodes, A.C., St. Clair, S.B., 2014. Fire severity alters plant regeneration patterns and defense against herbivores in mixed aspen forests. Oikos 123, 1479-1488.

Warner, J.H., Harper, K.T., 1972. Understory characteristics related to site quality for aspen in Utah. Brigham Young University Science Bulletin, Biological Series.

Westerling, A.L., Hidalgo, H.G., Cayan, D.R., Swetnam, T.W., 2006. Warming and earlier spring increase western US forest wildfire activity. Science 313, 940-943.

White, P.S., 1979. Pattern, process, and natural disturbance in vegetation. The Botanical Review 45, 229.

White, P.S., Pickett, S.T.A., 1985. Natural disturbance and patch dynamics: an introduction. The Ecology of Natural Disturbance and Patch Dynamics. Orlando, FL, U. S.A., Academic Press, Inc.: 3-13.

Worrall, J.J., Egeland, L., Eager, T., Mask, R.A., Johnson, E.W., Kemp, P.A., Shepperd, W.D., 2008. Rapid mortality of Populus tremuloides in southwestern Colorado, USA For. Ecol. Manag. 255, 686-696.

Worrall, J.J., Marchetti, S.B., Egeland, L., Howell, B., 2010. Effects and etiology of sudden aspen decline in southwestern Colorado. USA. For. Ecol. Manag. 260, 638-648.

Worrall, J.J., Rehfeldt, G.E., Hamann, A., Hogg, E.H., Marchetti, S.B., Michaelian, M., Gray, L.K., 2013. Recent declines of Populus tremuloides in North America linked to climate. For. Ecol. Manag. 299, 35-51.

Yang, J., Weisberg, P.J., Shinneman, D.J., Dilts, T.E., Earnst, S.L., Scheller, R.M., 2015. Fire modulates climate change response of simulated aspen distribution across topoclimatic gradients in a semi-arid montane landscape. Landscape Ecol. 30, 1055-1073.

Zasada, J.C., Viereck, L.A., 1975. The effect of temperature and stratification on germination on selected members of the Salicaceae in Interior Alaska. Can. J. Forest Res. 5, 333-337.

Zeigenfuss, L.C., Binkley, D., Tuskan, G.A., Romme, W.H., Yin, T., DiFazio, S., Singer, F.J., 2008. Aspen ecology in Rocky Mountain National Park: Age distribution, genetics, and the effects of elk herbivory: USGS Open-File Report 2008-1337. 